\title{
KETENTUAN PENGATURAN KAWIN KONTRAK DALAM PERSPEKTIF HUKUM POSITIF DI INDONESIA
}

\author{
Oleh : Sukindar
}

Fakultas Hukum Universitas 17 Agustus 1945 Samarinda

Jl.Ir.H.Juanda No 80 Samarinda

Email : sukindar1974@gmail.com

\begin{abstract}
Contract marriages are one of the 3 types of marriages known in Indonesia. As it is known that contract marriages are marriages made by certain parties with specific aims and objectives and within a certain period of time. So the marriage is actually a marriage that is not appropriate and deviates from the noble purpose of the actual marriage, which is to form an eternal household and only seek the pleasure of God, in accordance with the provisions as regulated in applicable laws in Indonesia.

Therefore, the purpose of this paper is to find out the actual arrangements related to the practice of contract marriages which are still widely practiced in Indonesia.

This type of research used in this study is normative juridical type of research, namely research conducted based on the legal scientific character of the normative side.

The results of the study showed that the practice of contract marriages that were carried out was not appropriate and violated the provisions of the legislation that acted as positive law in Indonesia. This is due to the contract marriage there are several things that were promised such as, a number of assets that must be issued and the deadline for the end of the marriage has been determined, then obviously such a marriage is a marriage arranged by the parties themselves and ignores the provisions of the applicable laws and regulations. While the regulations that specifically regulate contract marriages have not yet existed in Indonesia.
\end{abstract}

Keywords : Marriage, contract marriage, positive law 


\begin{abstract}
ABSTRAK
Perkawinan kontrak adalah salah satu dari 3 jenis perkawinan yang dikenal di Indonesia. Sebagaimana diketahui bahwa kawin kontrak merupakan perkawinan yang dilakukan oleh pihak-pihak tertentu dengan maksud dan tujuan tertentu serta dalam jangka waktu tertentu pula. Jadi perkawinan tersebut sebenarnya merupakan perkawinan yang tidak sesuai dan menyimpang dari tujuan mulia perkawinan yang sebenarnya, yaitu untuk membentuk rumah tangga yang kekal dan hanya mencari keridhaan Tuhan YME, sesuai dengan ketentuan sebagaimana diatur dalam perundang-undangan yang berlaku di Indonesia.

Oleh karena itu tujuan dari penulisan ini adalah untuk mengetahui pengaturan yang sebenarnya terkait adanya praktik kawin kontrak yang sampai saat ini masih banyak dilakukan di Indonesia.

Jenis penelitian yang digunakan pada penelitian ini adalah jenis penelitian yuridis normatif, yaitu penelitian yang dilakukan berdasar pada karakter keilmuan hukum dari sisi normatifnya.

Hasil penelitian menunjukan bahwa praktik perkawinan kontrak yang dilakakukan adalah tidak sesuai dan melanggar ketentuan peraturan perundang-undangan yang berlaku sebagai hukum posif di Indoneisa. Hal ini disebabkan pada perkawinan kontrak terdapat beberapa hal yang diperjanjikan seperti, sejumlah harta yang harus dikeluarkan dan batas waktu berakhirnya perkawinan telah ditentukan, maka jelas perkawinan yang demikian itu merupakan perkawinan yang diatur sendiri oleh para pihak dan mengabaikan ketentuan peraturan perundang-undangan yang berlaku. Sementara peraturan-peraturan yang memberikan pengaturan secara khusus terhadap kawin kontrak sampai saat ini belum ada di Negara Indonesia.
\end{abstract}

Kata Kunci : Perkawinan, Kawin Kontrak, Hukum Positif 


\section{PENDAHULUAN}

\section{A. Latar Belakang}

Perkawinan diartikan sebagai sebuah ikatan sosial atau ikatan perjanjian hukum antar pribadi untuk membentuk hubungan kekerabatan dan yang merupakan suatu pranata dalam budaya suatu daerah tertentu yang meresmikan hubungan antar pribadi yang biasanya intim dan seksual. Seseorang belum dapat dikatakan sebagai suami ataupun istri yang sah ketika seseorang laki-laki maupun perempuan belum melangsungkan perkawinan secara resmi sesuai dengan ketentuan peraturan perundang-undangan yang berlaku maupun menurut hukum masing-masing agama yang dipeluknya. Jadi Perkawinan itu pada umumnya dimulai dan diresmikan dengan mengadakan serangkaian upacara pernikahan yang maksud utamanya adalah untuk membentuk sebuah keluarga. Namun hal ini tergantung pula kepada budaya masing-masing daerah sebagai tempat dilangsungkannya perkawinan tersebut. Karena terkadang bentuk perkawinan dan tujuannya di masing-masing daerah bisa jadi berbeda-beda. Akan tetapi pada dasarnya perkawinan itu sebuah prosesi yang ekslusif didalamnya terdapat pelanggaran yang lazim disebut dengan perselingkuhan.

Apabila dicermati sebenarnya tujuan perkawinan itu sungguh mulia, yaitu untuk membentuk sebuah keluarga bahagia, kekal dan abadi berdasarkan Ketuhanan Yang Maha Esa. Sebagaimana terdapat dalam Pasal 1 Undang-Undang Nomor 1 tahun 1974 yang menjelaskan bahwa : "Perkawinan merupakan ikatan lahir dan batin antara seorang wanita dengan seorang pria sebagai suami istri dengan tujuan membentuk keluarga (rumah tangga) yang bahagia dan kekal berdasarkan Ketuhanan Yang Maha Esa."

Berdasarkan rumusan yang dijelaskan dalam Undang-Undang Perkawinan tersebut diatas, perkawinan tidak hanya didasarkan pada ikatan lahir ataupun bathin saja namun harus didasarkan pada keduaduanya yaitu lahir dan bathin. Karena pada dasarnya perkawinan merupakan suatu perbuatan hukum selain perbuatan keagamaan. Dikatakan sebagai perbuatan hukum sebab perbuatan tersebut dapat menimbulkan akibat hukum, karena setelah dilangsungkannya perkawinan akan timbul hak dan kewajiban yang dibebankan kepada para pihak yaitu kedua mempelai, sedangkan dikatakan sebagai perbuatan keagamaan sebab dalam praktik, pelaksanaan perkawinan selalu disesuaikan dengan ajaran masing-masing agama dan kepercayaan seperti yang telah dilakukan oleh para pendahulu yang telah memberikan peraturan dan tata cara mengenai pelaksanaan perkawinan.

Sebagaimana diketahui bahwa perkawinan tidak terjadi begitu saja, tetapi melalui sebuah proses yang diawali oleh para pihak yaitu pihak 
laki-laki dan pihak perempuan yang saling kenal-mengenal kemudian timbul perasaan saling menyukai dan merasa mampu untuk menjalin hubungan lebih jauh berupa jalinan hidup bersama untuk membentuk sebuah keluarga atau yang lazim disebut dengan rumah tangga. Namun demikian, pernikahan itu sendiri mempunyai syarat dan rukun yang sudah ditetapkan baik dalam Al-Qur'an maupun Al-Hadits. ${ }^{1}$ Sayuti Thalib memberikan pengertian bahwa perkawinan adalah perjanjian suci membentuk keluarga antara seorang laki-laki dengan seorang perempuan. Sedangkan Mahmud Yunus menjelaskan, perkawinan ialah akad antara calon laki istri untuk memenuhi hajat jenisnya menurut yang diatur oleh syariat. Selanjutnya Zahry Hamid merumuskan nikah menurut syara' ialah akad (ijab qabul) antara wali calon istri dan mempelai laki-laki dengan ucapan tertentu dan memenuhi rukun serta syaratnya. Bagi pihak-pihak yang akan melaksanakan pernikahan seluruh ulama' Hanafiyah sepakat bahwa perkawinan dilakukan secara suka rela dan atas kehendak sendiri. ${ }^{2}$

Berdasarkan beberapa pengertian perkawinan sebagaimana dijelaskan diatas, bisa disimpulkan bahwa perkawinan merupakan sebuah akad atau perhubungan hukum yang didasarkan atas perasaan suka rela dalam rangka mewujudkan hubungan antara seorang laki-laki dengan seorang perempuan untuk mewujudkan sebuah rumah tangga atau keluarga yang bahagia yang selalu dinaungi oleh suasana tenteram penuh rasa cinta, kasih dan sayang dengan cara-cara yang diperbolehkan dan diridhoi Allah SWT.

Jika dilihat dari beberapa definisi mengenai perkawinan tersebut diatas, perkawinan adalah sebuah prosesi yang sakral, bukanlah sebuah kegiatan yang dapat dilaksanakan dengan sewenang-wenang tanpa memperhatikan kaidah-kaidah sebagai pedoman pelaksanaan, sehingga maksud dan tujuan serta manfaat setelah dilangsungkannya perkawinan dapat tercapai. Untuk itu selain dari sisi adat, hukum dan secara agama, Islam adalah salah satu agama yang memandang perkawinan adalah sebagai sebuah peristiwa penting yang harus dilaksanakan dengan tata cara tertentu sehingga memenuhi unsur keabsahan baik secara norma hukum maupun agama.

Islam memandang perkawinan adalah fitrah manusia dan merupakan ibadah bagi seorang muslim dalam upaya penyempurnaan iman dan

${ }^{1}$ Abdurrahman, Himpunan Peraturan Perundang-undangan Tentang Perkawinan. (Jakarta: Akademika Pressindo, 1986), hal. 64.

${ }^{2}$ Muhammad Jawad Mughniyyah, Fiqh Lima Madzhab, (Jakarta: Lentera, 2001), 315. 
agamanya. Dengan menikah, seseorang telah memikul amanah sebagi bentuk tanggungjawab besar yang dibebankan kepadanya bagi keluarga yang akan dibimbing dan dipelihara menuju jalan kebenaran. Perkawinan juga memiliki manfaat yang cukup besar terhadap kepentingan sosial yang lain, seperti memelihara keberlangsungan hidup manusia, melanjutkan dan mengembangkan keturunan, memperlancar rezeki, menjaga kehormatan, menjaga keselamatan bersama dari berbagai penyakit yang dapat mengancam kelangsungan hidup manusia serta senantiasa menjaga ketenteraman secara menyeluruh baik jiwa dan raga.

Agar perkawinan dapat berjalan sesuai dengan ketentuan, maka syarat sahnya perkawinan juga menjajadi suatu hal yang tidak dapat dianggap sebagai hal sepele dalam pelaksanaan perkawinan tersebut, karena hal ini akan menjadi dasar bahwa seseorang dapat diakui secara hukum bahkan agama ketika perkawinan yang dilaksanakan itu memenuhi seluruh syarat-syarat yang telah ditentukan oleh agama maupun norma hukum. Selain itu hal ini akan menjadi penentu sebuah pasangan seorang lelaki dengan seorang perempuan telah diperbolehkan dan dianggap telah halal untuk melakukan hubungan suami istri sehingga terhindar dari perbuatan terlarang yaitu perzinaan. Perzinaan merupakan salah satu perbuatan yang sangat dilarang baik menurut norma agama maupun norma hukum, karena sesungguhnya perzinaan adalah perbuatan yang dapat menghancurkan nilai ibadah selain dapat mengganggu setiap manusia dalam menjalani hidup dan kehidupannya. Didalam Islam, zina termasuk kategori perbuatan dosa besar dan tidak hanya menjadi urusan bagi pribadi yang melakukan saja dengan Tuhannya, namun merupakan pelanggaran terhadap norma hukum yang layak untuk diberikan sanksi bagi pelakunya. Indonesia adalah Negara yang penduduknya mayoritas pemeluk Agama Islam, oleh karena itu, hukum Islam masih sangat berpengaruh kuat dalam penerapan sikap moral dan kesadaran terhadap hukum bagi masyarakatnya.

Islam mempergunakan kebiasaan/tradisi cukup sederhana dalam prosesi perkawinan, hal ini bertujuan agar para pihak tidak sampai terjebak dan terseret dalam perbuatan zina. Adapun cara sederhana yang dimaksud tersebut sebenarnya sejalan dengan Undang-Undang Perkawinan di Indonesia tepatnya terdapat pada pasal 2 ayat 1 yang menyatakan : "Perkawinan adalah sah apabila dilakukan menurut hukum masing-masing agama dan kepercayaannya." Berdasar pada muatan pasal itu seperti telah memberikan peluang bagi penganut hukum adat untuk mengikuti bahkan cenderung berpedoman pada hukum Islam tersebut dalam prosesi perkawinan. Selain itu penyebabnya adalah karena kemauan masyarakat itu sendiri yang memang menghendaki seperti itu. Sebagai contoh perkawinan dengan cara adat yang sampai saat ini masih 
diberlakukan adalah tidak dilakukannya pencatatan kepada petugas/pejabat berwenang yang lazim disebut dengan nikah siri. Pernikahan ini hanya dilangsungkan di hadapan penghulu atau seorang ahli bidang agama dengan syarat-syarat sesuai dengan ketentuan syariat Agama Islam, namun setelah prosesi pernikahan dilaksanakan selanjutnya para pihak tidak pernah mencatatkan perkawinannya itu ke kantor yang berwenang melakukan pencatatan perkawinan.

Selain pernikahan siri sebagaimana dimaksud, ternyata banyak terjadi dikalangan masyarakat daerah tertentu yang melangsungkan perkawinan dengan tujuan tertentu yang lazim disebut dengan perkawinan kontrak. Kawin kontrak adalah suatu bentuk perkawinan yang dibatasi oleh waktu tertentu sesuai yang diperjanjikan keduabelah pihak. Sayyid Syabiq memberikan penjelasan kawin kontrak adalah adanya seorang pria mengawini wanita selama sehari, atau seminggu, atau sebulan. ${ }^{3}$ Dalam islam nikah kontrak atau diistilahkan dengan nikah mutah diartikan sebagai pernikahan kesenangan. Menurut Mazhab Syiah, nikah mutah adalah pernikahan dalam masa waktu yang telah ditetapkan dan setelah itu ikatan perkawinan tersebut sudah tidak berlaku lagi. Contohnya, seorang lelaki melakukan perkawinan dengan akad nikah sebagai berikut, "Aku menikahimu selama satu bulan atau satu tahun." Kemudian, wanita itu menjawab, "Aku terima." Maka masa nikah suami-istri akan berakhir dalam waktu sesuai dengan akad tersebut. Sedangkan sunni berpandangan, pernikahan seperti ini hanya diperkenankan ketika masa peralihan antara zaman jahiliah menuju zaman keislaman, yaitu ketika perzinaan menjadi masalah yang lazim dilakukan oleh masyarakat. Menurut mazhab Sunni, pernikahan mut'ah tersebut adalah dianggap tidak sah dan tidak diperbolehkan karena pelaksanaannya tidak dilakukan dihadapan wali dan saksi, sehingga dianggap mengarah pada perbuatan zina, bahkan dapat dikategorikan sebagai perbuatan pelacuran karena terdapat unsur biaya yang diperlukan sebagai bentuk tujuan pernikahannya.

\section{B. Rumusan Masalah}

Berdasarkan latar belakang masalah sebagaimana dijelaskan diatas permasalahan yang akan dicari jawabnya dalam penulisan ini adalah bagaimana ketentuan pengaturan mengenai kawin kontrak dalam perspektif Hukum Positif di Indonesia.

https://updatetalas.wordpress.com/2016/09/28/ pengertian-nikah-kontrak/, diakses 27/6/2020 Pukul 10.51 Wita 


\section{Tujuan Penelitian}

Tujuan yang hendak dicapai pada penelitian ini adalah untuk mengetahui ketentuan pengaturan terhadap pelaksanaan kawin kontrak dalam perspektif Hukum Positif di Indonesia.

\section{Manfaat Penelitian}

Berdasarkan tujuan penelitian yang hendak dicapai, manfaat penelitian ini secara teoritis adalah untuk mengembangkan ilmu bidang hukum dan sebagai acuan ataupun referensi bagi penelitian-penelitian berikutnya yang ada relevansinya dengan pelaksanaan kawin kontrak. Sedangkan manfaat secara praktis, penelitian ini dapat dijadikan sebagai tambahan pengetahuan bagi para pembaca dan masyarakat secara umum, khususnya kepada pihak-pihak tertentu yang ada niatan untuk melangsungkan perkawinan dengan cara kontrak.

\section{KERANGKA DASAR TEORI}

\section{A. Tinjaun Umum tentang Hukum}

Pembahasan mengenai rumusan pengertian hukum, sampai saat ini, belum diperoleh satu rumusanpun yang dapat dijadikan sebagai rumusan baku mengenai arti dari hukum. Bahkan kesepahaman para ahli berkaitan dengan definisi hukum hingga kini belum dapat diperoleh. Sebenarnya cukup banyak para pakar dan ahli bahkan sarjana hukum yang berusaha mencoba merumuskan definisi atau pengertian hukum, namun belum satupun diperoleh sebuah rumusan mengenai definisi hukum dari ahli-ahli atau pakar-pakar atau bahkan sarjana-sarjana hukum tersebut yang dapat memberikan definisi hukum sehingga diterima oleh semua pihak. Ketidakadaan satu rumusan pengertian hukum dari seluruh pakar-pakar dan ahli-ahli hukum yang dapat dijadikan sebagai pedoan oleh publik, maka akan memungkinkan terjadinya memutasi terhadap permasalahan terkait ketidaksepahaman dalam pemberian definisi mengenai hukum tersebut yaitu, munculnya berbagai opini seperti keragu-raguan terhadap perlu tidaknya pemberian definisi hukum atau kemungkinan tidaknya publik membuat pengertian hukum yang selanjutnya akan dapat berkembang menjadi perlu tidaknya hukum didefinisikan.

Ketidakadaan pengertian hukum yang jelas menjadi salah satu kendala bagi pihak-pihak yang akan mempelajari ilmu bidang hukum. Sebagaiman diketahui langkah awal yang dilakukan dalam mempelajari sebuah bidang ilmu seperti halnya ilmu hukum, pasti melalui proses pemahaman awal yang dimulai dari pemahaman terhadap definisi hukum secara umum, selanjutnya bertahap mempelajari hukum dengan segala aspeknya secara menyeluruh. Bagi kalangan awam definisi hukum itu 
tidak terlalu penting, justru yang dianggapnya penting adalah penegakan dan bentuk perlindungan hukumnya yang dapat diberikan kepadanya. Tetapi, bagi masyarakat yang ingin mendalami lebih jauh mengenai hukum, tentunya perlu mengetahui definisi hukum terlebih dahulu. Rumusan mengenai pengertian hukum secara umum minimal mengandung unsur-unsur sebagai berikut :

Pada dasarnya hukum itu memberikan pengaturan terhadap perilaku atau tindakan manusia dalam menjalani hidup bermasyarakat. Peraturan yang ada memuat perintah maupun larangan sebagai pedoman untuk berbuat atau tidak berbuat sesuatu. Hal ini ditujukan untuk mengatur tingkah laku manusia agar tidak menimbulkan permasalahan yang dapat mengganggu bahkan menimbulkan terjadinya kerugian bagi kepentingan bersama.

Peraturan-peraturan hukum tersebut ditetapkan oleh pihak-pihak yang berwenang membuatnya dan tidak boleh dibuat orang per orang, melainkan harus melibatkan pihak-pihak terkait seperti lembaga atau badan tertentu yang memiliki kewenangan dalam melakukan perumusan dan penetapan sebuah aturan yang memilki sifat mengikat bagi masyarakat secara umum.

Salah satu sifat hukum adalah bersifat memaksa. Hukum diadakan untuk dipatuhi dan bukan untuk dilanggar. Dalam rangka menegakkan hukumpun telah diatur pula terkait pihak-pihak yang diberikan kewenangan untuk malakukan pengawasan walupun tidak jarang sampai dengan tindakan represif. Selain itu, sifat hukum yang lain adalah bersifat fakultatif atau melengkapi.

Berikut disampaikan beberapa pengertian hukum menurut beberapa pendapat ahli :

1. Menurut Hans Kelsen, hukum adalah suatu sistem norma-norma yang mengatur perilaku manusia. ${ }^{4}$

2. Menurut J.van Kan dan J.H. Beekhuis, hukum adalah " suatu perhimpunan kaidah-kaidah yang bersifat memaksa, atau dengan perkataan lain, suatu rumpunan pergaulan hidup yang bersifat memaksa."

3. Menurut Black's Law Dictionary, hukum dalam arti umum adalah keseluruhan peraturan bertindak atau berperilaku yang ditentukan oleh kekuasaan pengendali, dan mempunyai kekuatan sah bersifat

${ }^{4}$ Hans Kelsen,2002,Pure Theory of Law, terjemahan Max Knight dari reine Rechtslehre. The Law book Exchange Ltd,hal.4 : “... a system of noems regulating human behavior."

5 J.van Kan dan J.H. Beekhuis,Pengantar Ilmu Hukum,Pustaka Sarjana,tanpa tahun, hal.183 
mengikat; ${ }^{6}$ atau, apa yang harus ditaati dan diikuti oleh warga Negara dengan akibat sanksi atau konsekuensi sah adalah huku. ${ }^{7}$

4. Menurut Ensiklopedi Indonesia, hukum adalah "peraturan yang menentukan, bagaimana hendaknya kelakuan orang dalam masyarakat."

Secara umum hukum adalah peraturan yang berupa kaidah dan adanya pemberian sanksi yang bertujuan untuk mengatur perilaku manusia, menjaga ketertiban, mewujudkan keadilan dan mencegah kemungkinan adanya kekacauan. Hukum menjadi pedoman bagi masyarakat dalam bertindak. Masyarakat juga berhak mendapatkan kepastian dan perlindungan hukum. Pemberlakuan sanksi juga diterapkan bagi pihak yang melanggar hukum.

\section{B. Penjelasan Mengenai Hukum Positif}

Selain pengertian hukum secara umum sebagaimana dijelaskan diatas, selanjutnya akan kemukakan penjelasan mengenai pengertian hukum positif. Hukum Real (Bahasa Latin: ius positum) adalah hukum yang dibuat oleh manusia yang mewajibkan atau menetapkan suatu tindakan. Istilah ini juga mendeskripsikan penetapan hak-hak tertentu untuk suatu individu atau kelompok. Hukum positif juga dideskripsikan sebagai hukum yang berlaku pada waktu tertentu (masa lalu atau sekarang) dan di tempat tertentu. ${ }^{9}$ Hukum positif merupakan serangkaian asas dan norma hukum yang berlaku pada saat ini disuatu daerah tertentu, dapat berbentuk lisan maupun tulisan yang keberlakuannya mengikat secara khusus dan umum, ditegakkan oleh suatu lembaga peradilan atau pemerintahan yang ada dalam suatu negara. Meskipun hukum positif dijelaskan sebagai hukum yang berlaku pada saat ini akan tetapi pada dasarnya tidak meninggalkan hukum yang berlaku pada masa lalu.

Berikut beberapa contoh hukum positif yang diberlakukan di Indonesia :

1. Hukum Pidana

2. Hukum Perdata

3. Hukum Tata Negara

${ }^{6}$ H.C. Black, Black's Law Dictionary, West publishing Co. St. Paul Minn., 1979, hlm.795: "Law, in its generic sense, is a body of rules of action or conduct prescribed by the controlling authority, and having binding legal force".

7 Ibid: "That which must be obyed and followed by citizens subject to sanctions or legal consequenses is a law."

${ }^{8}$ Ensiklopedi Indonesia, (Jakarta: Ichtiar baru-Van Hoeve,1982), Jilid 3, hal. 1344

${ }^{9}$ https://id.wikipedia.org/wiki/Hukum_positif\#: :text=Hukum\%20Real\%20(Bahas a\%20Latin\%3A\%20ius,mewajibkan\%20atau\%20menetapkan\%20suatu\%20tindakan.\&te xt=Hukum\%20positif\%20juga\%20dideskripsikan\%20sebagai,sekarang)\%20dan\%20di\% 20tempat\%20tertentu. Diakses pada tanggal 30/6/2020 pada pukul 12.05 Wita. 
4. Hukum Tata Usaha Negara

5. Peraturan Perundang-undangan

Berkaitan dengan tata urutan atau hierarki Peraturan Perundangundangan sesuai dengan ketentuan perundang-undangan yang berlaku di Indonesia tertuang dalam Undang-Undang Nomor 12 tahun 2011 tentang Pembentukan Peraturan Perundang-undangan yakni :

1. Undang-Undang Dasar Negara Republik Indonesia tahun 1945

2. Tap MPR

3. UU/PERPPU

4. Peraturan Pemerintah

5. Peraturan Presiden

6. Peraturan Daerah Provinsi

7. Peraturan Daerah Kabupaten/Kota

\section{Perkawinan menurut sudut pandangan Hukum Positif di Indonesia}

Pasal 1 Undang-Undang Nomor 1 Tahun 1974 tentang Perkawinan memberikan penjelasan mengenai definisi perkawinan. Perkawinan adalah ikatan lahir batin antara seorang pria dan seorang wanita sebagai suamiistri dengan tujuan membentuk keluarga (rumah tangga) yang bahagia dan kekal berdasarkan ketuhanan yang Maha Esa.

Rumusan tersebut di atas memuat beberapa hal yang harus diperhatikan yaitu

1. Terdapat kata seorang pria dan seorang wanita, maksud dari kata-kata tersebut adalah bahwasanya perkawinan hanya boleh dilakukan antara seseorang dengan seseorang yang memiliki jenis kelamin berbeda. Dengan demikian berarti dalam perkawinan sesungguhnya tidak dibenarkan ketika ada seseorang yang berjenis kelamin sama berniat untuk melangsungkan perkawinan, meskipun perkawinan dengan model seperti ini terjadi dibeberapa Negara di luar Indonesia.

2. Kemudian terdapat kata suami istri, mengacu pada kata-kata tersebut memberikan pemahaman bahwa perkawinan ialah terjadinya pertemuan antara 2 jenis kelamin berbeda dalam sebuah rumah tangga atau keluarga, tetapi tidak sekedar dalam konteks "hidup bersama".

3. Selanjutnya dalam definisi tersebut disebutkan juga serangkaian katakata yang merupakan tujuan dari sebuah perkawinan yaitu membentuk keluarga atau rumah tangga yang bahagia dan kekal. Berdasar pada tujuan perkawinan tersebut mengisyaratkan bahwa sesungguhnya perkawinan adalah sebuah praktik sosial dan keagamaan yang tidak dapat dijadikan sebagai prosesi yang main-main atau hanya untuk bersenang-senang saja sebagaimana dalam istilah keagamaan, istilah 
perkawinan yang demikian itu lazim disebut dengan istilah perkawinan mut'ah.

4. Kata-kata terakhir yang disebutkan dalam Pasal tersebut yaitu berdasarkan Ketuhanan Yang Maha Esa. Serangkaian kata-kata tersebut mensyaratkan bahwa prosesi perkawinan dalam Islam adalah sebuah peristiwa keagamaan dan dilangsungkan dalam rangka menjalankan perintah agama.

Perjanjian nikah sebagaimana dimaksud dalam penjelasan perkawinan tersebut diatas terdiri atas 3 kategori yaitu :

1. Tidak dapat dilaksanakannya pernikahan apabila dalam keadaan terpaksa yaitu tidak adanya kerelaan antara kedua pihak.

2. Kedua insan yang mengikrarkan diri dalam sebuah perjanjian pernikahan tersebut, masing-masing mempunyai hak ketika akan memutuskan mengenai perjanjian pernikahan sesuai dengan ketentuan yang berlaku.

3. Perjanjian pernikahan tersebut memberikan pengaturan mengenai batas-batas peraturan terkait hak dan kewajiban para pihak. Perjanjian perkawinan tersebut sesungguhnya tidak memiliki kesamaan dengan perjanjian yang lain, seperti halnya perjanjian tukar-menukar, sewa menyewa,jual beli dan lain-lain.

Menurut Mr. Wirjono Prodjojodikoro perbedaan antara persetujuan perkawinan dan persetujuan biasa adalah persetujuan biasa semua pihak berhak menentukan sendiri pokok perjanjian asalkan sesuai dengan peraturan dan tidak melanggar asusila, sedangkan persetujuan perkawinan isi dari perjanjian perkawinan sudah ditentukan oleh hukum. ${ }^{10}$

Perlu diketahui bahwa dalam sebuah prosesi perkawinan terdapat syarat- syarat dan rukun yang harus dipenuhi, jika tidak maka perkawinan tersebut ternyata dapat dibatalkan. Sebagaimana dijelaskan dalam Pasal 22 Undang-Undang tentang Perkawinan menjelaskan : "Perkawinan dapat dibatalkan apabila para pihak tidak memenuhi syarat-syarat untuk melangsungkan perkawinan". Selanjutnya Pasal 27 (ayat 1) UndangUndang tersebut menyatakan bahwa "Seseorang suami atau isteri dapat mengajukan permohonan pembatalan perkawinan apabila perkawinan dilangsungkan di bawah ancaman yang melanggar hukum". Kemudian pasal 6 (ayat 1) masih menurut Undang-Undang tentang perkawinan membahas tentang syara-syarat perkawinan yaitu bahwa : "Perkawinan didasarkan atas persetujuan kedua calon mempelai." Oleh karenanya perkawinan yang dilangsungkan tidak atas persetujuan dari kedua calon

${ }^{10}$ Soemiyati, 1986,Hukum Perkawinan Islam dan Undang-undang Perkawinan, Yogyakarta: Liberty Yogyakarta, hal.9. 
mempelai sesungguhnya menyalahi dan tidak sesuai dengan ketentuan perundang-undangan yang berlaku.

\section{Penjelasan mengenai Kontrak}

Perlu diketahui bahwa pada dasarnya secara umum kontrak itu sama dengan perjanjian. Meskipun terdapat pendapat yang memberikan definisi bahwa perjanjian adalah suatu peristiwa dimana seorang berjanji kepada seorang lain atau dimana dua orang itu saling berjanji untuk melaksanakan suatu hal. Sedangkan kontrak merupakan perjanjian yang dibuat oleh para pihak dalam bentuk tertulis.

Berkaitan dengan definisi kontrak sebagimana dijelaskan dalam KUH Perdata Pasal 1313 bahwa : "Perjanjian adalah suatu perbuatan dengan mana satu pihak atau lebih mengikatkan diri terhadap satu orang atau lebih,". Sedangkan doktrin (teori lama) mengartikan perjanjian adalah "Perbuatan hukum berdasarkan kata sepakat untuk menimbulkan akibat hukum." Selanjutnya pendapat teori baru yang disampaikan oleh Van Dunne, dinyatakan bahwa perjanjian, adalah "Suatu hubungan hukum antara dua pihak atau lebih berdasarkan kata sepakat untuk menimbulkan akibat hukum."11 Dalam Burgerlijk Wetboek (BW) yang selanjutnya diterjemahkan oleh R. Subekti, dan R. Tjitrosudibio menjadi KUH Perdata, pembahasan terkait hukum perjanjian diatur didalam Buku III yaitu tentang Perikatan, pada bagian tersebut memberikan pengaturan dan memuat mengenai hukum kekayaan dan mengenai hak dan kewajiban yang diberlakukan bagi orang perorang atau pihak-pihak tertentu.

Merujuk pada beberapa pemikiran para ahli mengenai perjanjian sebagaimana telah dipaparkan sebelumnya. Maka, dapat disimpulkan, perjanjian adalah "suatu perbuatan yang dilakukan oleh seseorang atau lebih untuk melaksanakan suatu hal tertentu dengan seseorang atau lebih berdasar atas kesepakatan kedua belah pihak". Hal ini berarti ketika seseorang mengadakan perjanjian dengan orang lain, maka akan timbul hubungan hukum diantara para pihak tersebut, yang lazim dinamakan dengan perikatan. Jika dilihat dari sudut pandang bentuknya, perjanjian merupakan suatu rangkaian kata-kata yang memuat janji-janji atau kesediaan dari para pihak baik berupa ucapan maupun tulisan. Sedangkan perikatan menurut Subekti adalah "suatu perhubungan hukum antara dua orang atau dua pihak, berdasarkan mana pihak yang satu berhak menuntut sesuatu hal dari pihak yang lain, dan pihak yang lain berkewajiban untuk memenuhi tuntutan itu. ${ }^{12}$ Jadi hubungan antara perikatan dengan perjanjian adalah bahwa perjanjian merupakan salah satu penyebab

\footnotetext{
${ }^{11}$ Salim HS,2011,Pengantar Hukum Perdata Tertulis (BW), Sinar Grafika, Jakarta,hal. 161

${ }^{12}$ Soebekti,2001,Hukum Perjanjian,Cet 18,PT.Intermasa,Jakarta,hal.1
} 
lahirnya perikatan. Dengan kata lain bahwa perjanjian adalah salah satu sumber perikatan.

Sedangkan hukum perjanjian menurut teori ilmu hukum digolongkan sebagai hukum tentang pribadi seseorang dan hukum kekayaan, mengingat hal tersebut merupakan percampuran antara kecakapan dari seseorang dalam melakukan suatu tindakan dan berhubungan dengan segala sesuatu yang diatur didalam perjanjian seperti halnya sesuatu yang dihargai dengan uang.

Istilah dari hukum perjanjian atau hukum kontrak pada dasarnya adalah terjemahan dari bahasa Inggris yaitu contract law, sedangkan didalam bahasa Belanda diistilahkan dengan overeenscomsrecht.

\section{E. Kawin Kontrak Menurut Pandangan Norma Hukum dan Norma Agama}

Sebagaimana diketahui bahwa terdapat 3 jenis perkawinan yang dikenal di Indonesia, yaitu nikah, kawin siri, dan nikah kontrak. Kawin merupakan pernikahan sah menurut agama jika kemudian dilanjutkan dengan melakukan pencatatan di dinas kependudukan dan catatan sipil. Ketika pernikahan berlangsung dengan menghadirkan penghulu sebagai wakil pemerintah untuk melakukan pencatatan bagi pasangan yang sudah melakukan ijab qabul, maka pasangan tersebut sudah diakui sebagai pasangan yang sah menurut agama dan negara. Sebagai bukti keabsahannya adalah dengan diterbitkannya buku nikah untuk kedua mempelai tersebut.

Sementara berdasarkan Undang-Undang Nomor 1 Tahun 1974 Tentang Perkawinan, pasal 1 menyebutkan bahwa perkawinan ialah ikatan lahir bathin antara seorang pria dengan seorang wanita sebagai suami isteri dengan tujuan membentuk keluarga (rumah tangga) yang bahagia dan kekal berdasarkan Ketuhanan Yang Maha esa.

Pasal 2 (ayat 1) "Perkawinan adalah sah, apabila dilakukan menurut hukum masing-masing agamanya dan kepercayaannya itu." Selanjutnya (ayat 2) menjelaskan "Tiap-tiap perkawinan dicatat menurut peraturan perundang-undangan yang berlaku. Berikutnya Pasal 3 (ayat 1) menyebutkan bahwa "Pada azasnya dalam suatu perkawinan seorang pria hanya boleh mempunyai seorang isteri. Seorang wanita hanya boleh mempunyai seorang suami. Sedangkan (ayat 2) Pengadilan dapat memberi izin kepada seorang suami untuk beristeri lebih dari seorang apabila dikehendaki oleh pihak-pihak yang bersangkutan. Dari penjelasan ayat demi ayat pada pasal-pasal tersebut dengan tegas memberikan pejelasan bahwa dalam sebuah perkawinan terdapat hal-hal yang harus dipatuhi agar perkawinan yang dilakukan itu sah dimata agama dan hukum, yaitu wajib 
dicatatkan kepada pihak yang berwenang untuk melakukan pencatatan perkawinan.

Selanjutnya nikah siri menurut Ustadz Fauzan, secara agama sah dalam Islam tapi tidak tercatat di dinas kependudukan dan catatan sipil. Pola pernikahan ini biasanya digunakan oleh orang yang melakukan poligami. ${ }^{13}$ Salah satu permasalahan yang dapat timbul dalam pernikahan siri adalah ketika pasangan tersebut sudah memiliki anak. Karena anak yang dilahirkan pada pernikahan siri tersebut tidak dapat memperoleh akta kelahiran, sesuai dengan ketentuan salah satu syarat untuk penerbitan akta kelahiran adalah orang tua dari anak tersebut harus mempunyai buku nikah yang ditandatangani oleh penghulu sehingga perkawinannya diakui oleh negara.

Kemudian yang ketiga adalah kawin kontrak. Penjelasan mengenai kawin kontrak sampai dengan tulisan ini ditulis belum ada sama sekali satu peraturan perundang-undanganpun yang memberikan penjelasan dan pengaturan mengenai kawin kontrak. Dalam praktik diketahui bahwa pernikahan kontrak terjadi dengan melakukan perjanjian menggunakan batasan waktu tertentu. Biasanya maharnya akan disesuaikan dengan lamanya jangka waktu jalinan atau hubungan perkawinan kontrak tersebut direncanakan, bahkan bisa saja semua perjanjian mengenai perkawinan kontrak tersebut berdasar pada kesepakatan dari kedua belah pihak. Berikut beberapa pendapat mengenai pengertian kawin kontrak dalam islam :

1. Abdus Salam Nawawi berpendapat kawin kontrak dikenal dengan istilah kawin mut'ah. Sifat kawin mut'ah ini, lebih menitikberatkan pada kesenangan yang dibatasi oleh waktu tertentu. ${ }^{14}$

2. Rifyal Ka'bah berpendapat bahwa kawin mut'ah lebih mengarah pada kesenangan belaka. Perkawinan tersebut adalah kawin main-main dengan tujuan hanya untuk bersenang-senang. ${ }^{15}$

Mengacu kepada pendapat-pendapat tersebut dapat disimpulkan bahwa kawin kontrak itu sesungguhnya merupakan kawin dengan tujuan tertentu yang cenderung mengarah kepada pencideraan terhadap kesucian dan kemurnian hakikat perkawinan yang sebenarnya, baik dari sudut pandang norma hukum maupun norma agama. Karena tersirat adanya perkawinan yang sengaja dilakukan oleh orang-orang tertentu yang hanya

\footnotetext{
${ }^{13}$ https://muslim.okezone.com/read/2019/12/24/614/2145587/ini-penjelasan-lengkaptentang-hukum-kawin-kontrak-dalam-islam?page=2 diakses pada tanggal 3/7/2020 pukul 07.21 Wita

14 https://www.hukumonline.com/berita/baca/hol15650/kawin-kontrak-antaraagama-hukum-dan-realita/ diakses pada tanggal 28/6/2020 pukul 14.03 Wita

${ }^{15}$ Ibid
} 
sebatas untuk pemenuhan kebutuhan biologis saja, dan pada perkawinan kontrak juga terkesan sebagai perkawinan yang main-main hanya untuk memburu kesenangan belaka.

\section{PEMBAHASAN}

Sebagaimana diketahui bahwa dalam sebuah prosesi pernikahan itu dilakukan dengan mengadakan suatu perjajian atau akad dalam rangka mengikatkan diri antara seorang pria dengan seorang wanita untuk menghalalkan hubungan kelamin diantara keduanya dan dilakukan dengan dasar suka sama suka atau sukarela dan keikhlasan dari kedua pihak tersebut dengan tujuan mewujudkan kebahagiaan hidup berumah tangga atau berkeluarga yang dinaungi oleh rasa cinta, kasih, sayang dan ketentraman dengan cara yang diridhoi Allah SWT. Berdasar pada pemahaman penjelasan mengenai pernikahan tersebut terdapat kata “...perjanjian untuk mengikatkan diri...". Hal ini memberikan gambaran bahwa dalam prosesi perkawinan setelah pengucapan ijab qabul yang dipandu oleh pejabat berwenang dan disaksikan oleh para saksi, bahkan sebagian besar didampingi oleh pihak keluarga masing-masing mempelai, sejak saat itulah terhadap para pihak (mempelai pria dan wanita) telah terjadi perikatan atau hubungan hukum diantara keduanya sebagai hasil ikrar yang telah diucapkan tersebut. Tidak cukup sampai disitu, setelah pengucapan ijab qabul masih terdapat dua prosesi yang harus dilalui, yaitu pembacaan sighat taqlid atau janji nikah yang dibacakan oleh mempelai pria dan terakhir penandatanganan buku nikah. Setelah semuanya dilakukan maka secara norma hukum maupun agama para pihak telah sah dikatakan sebagai suami istri dan telah melekat hak dan kewajiban sebagai konsekuensi yang harus diemban oleh para pihak tersebut.

KUH Perdata memberikan pandangan bahwa perkawinan itu hanya sebatas hubungan Perdata saja. Pada asasnya perkawinan merupakan suatu akad atau perjanjian yang dilakukan oleh dua orang berbeda jenis kelamin dalam rangka membentuk rumah tangga atau keluarga bahagia dan kekal berdasarkan Ketuhanan Yang Maha Esa.

Menurut KUH Perdata pengaturan tentang syarat-syarat sahnya perjanjian dijelaskan pada Pasal 1320. Pada pasal tersebut dijelaskan ada 4 syarat sahnya perjanjian yakni :

1. Sepakat mereka yang mengikatkan dirinya;

2. Kecakapan untuk membuat suatu perikatan;

3. Suatu hal tertentu; dan

4. Suatu sebab yang halal.

Selanjutnya dalam doktrin ilmu hukum yang berkembang, syarat pertama dan kedua digolongkan ke dalam syarat subyektif, karena kedua 
syarat tersebut merupakan syarat yang menyangkut unsur subjek (pihak) yang melakukan perjanjian, selanjutnya disebut sebagai syarat subjektif. Sedangkan syarat yang ketiga dan keempat merupakan syarat yang menyangkut unsur objek perjanjian, selanjutnya disebut sebagai syarat objektif. Apabila tidak terpenuhinya salah satu syarat dari keempat syarat tersebut perjanjian dianggap sebagai sebuah perjanjian yang cacat, secara hukum perjanjian akan dapat dibatalkan atau bahkan batal demi hukum. Jika perjanjian yang dibuat oleh para pihak tidak memenuhi syarat subyektif, maka perjanjian dapat dibatalkan, sedangkan jika perjanjian tersebut tidak memenuhi syarat obyektif, maka perjanjian batal demi hukum.

Sedangkan mengenai perkawinan terdapat beberapa syarat yang harus dipenuhi agar perkawinan dapat dilaksanakan adalah:

1. Persetujuan kedua calon mempelai;

2. Pria sudah berumur 19 tahun, dan wanita 16 tahun;

3. Izin orang tua atau pengadilan apabila belum berumur 21 tahun;

4. Tidak terikat dalam suatu perkawinan;

5. Tidak bercerai untuk kedua kalinya dengan suami atau istri yang sama hendak dikawini;

6. Bagi janda, sudah lewat waktu tunggu;

7. Sudah memberi tahu kepada pegawai pencatat perkawinan sekurangkurangnya 10 hari sebelum perkawinan dilangsungkan;

8. Tidak ada pihak yang mengajukan pencegahan perkawinan;

9. Tidak terdapat larangan kawin. ${ }^{16}$

Namun dari beberapa uraian mengenai syarat perkawinan sebagaimana disebutkan diatas pada syarat yang kedua yaitu mengenai syarat umur, telah dilakukan perubahan oleh Undang-Undang Nomor 16 tahun 2019 yang merupakan perubahan dari Undang-Undang Nomor 1 tahun 1974 tentang Perkawinan. Bahwa syarat umur menurut UU tersebut baik pria maupun wanita ketika akan melangsungkan perkawinan harus sudah genap berumur 19 tahun.

Selanjutnya berkaitan dengan kawin kontrak dapat dipahami bahwa perkawinan kontrak itu adalah adanya seorang pria yang mengawini seorang wanita melalui perjanjian atau akad mengenai suatu hal tertentu seperti perjaanjian tentang seberapa besar jumlah yang dapat diberikan untuk mempelai wanita, kemudian jangka waktu yang dibutuhkan untuk melangsungkan perkawinan tersebut. Selanjutnya perkawinan akan dianggap selesai ketika jangka waktu yang diperjanjikan tersebut tiba. Sejak saat itu pasangan tersebut dinyatakan tidak lagi sebagai suami istri

16 Wahjono Darmabrata dan Surini Ahlan, Hukum Perkawinan dan Hukum Keluarga Indonesia, Fakultas Hukum Universitas Indonesia, Jakarta, 2004, hlm. 17. 
dan tidak ada kewajiban bagi kedua belah pihak untuk melakukan kewajiban memberi nafkah, tempat tinggal bahkan terkait dengan hak waris. Berakhirnya perkawinan tanpa harus dilakukan dengan cara talak, karena sudah disepakati waktu berakhirnya perkawinan tersebut sebagaimana dijelaskan dalam isi perjanjian.

Analisis penulis terhadap praktik perkawinan kontrak, berpedoman pada Pasal 1332 KUH Perdata yang memberikan penjelasan bahwa segala sesuatu yang dapat diperjanjikan adalah segala obyek perjanjian berupa barang yang dapat diperjual belikan atau diperdagangkan. Sedangkan sebagi bentuk obyek perjanjian dalam perkawinan kontrak adalah perkawinan yang dibatasi oleh waktu tertentu, sementara perjanjian obyek tidak dapat dikategorikan sebagai suatu barang yang dapat diperdagangkan. Jadi jelas perjanjian mengenai obyek yang demikian itu secara hukum tidak memenuhi syarat sahnya perjanjian yaitu syarat objektif yang disebut juga dengan suatu hal tertentu, yang mana sesuatu yang dijadikan sebagai objek suatu perjanjian haruslah jelas dan dapat ditentukan jenisnya. Syarat objektif berikutnya yang tidak dapat dipenuhi adalah suatu sebab yang halal. Perjanjian perkawinan yang dilakukan dalam kawin kontrak sangatlah bertentangan dengan perjanjian perkawinan yang diatur dalam Kitab Undang-Undang Hukum Perdata Pasal 1337, Suatu sebab adalah terlarang jika sebab itu dilarang oleh Undang-Undang, atau bila sebab itu bertentangan dengan kesusilaan atau dengan ketertiban umum. Kemudian bertentangan dengan UndangUndang no 1 tahun 1974 tentang Perkawinan khususnya Pasal 1 yang mensyaratkan bahwa perkawinan itu harus dilakukan dengan niat dan tujuan yang tulus untuk membentuk sebuah keluarga atau rumah tangga yang bahagia dan kekal, bukan hanya sekedar untuk sementara waktu saja dan tidak kekal. Hal ini bertentangan juga bertentangan juga dengan Kompilasi Hukum Islam (KHI) Pasal 2, 5 dan 6. Mengenai isi dalam perjanjian perkawinan pada kawin kontrak pada umumnya mengatur tentang lamanya atau jangka waktu dari perkawinan tersebut, kemudian kompensasi yang pastinya berupa sejumlah uang sesuai dengan hasil kesepakatan para pihak, hak dan kewajiban antara para pihak, dan berbagai hal lain yang memang dianggap perlu untuk diperjanjikan.

Perkawinan dianggap sah ketika sudah memenuhi rukun dan syarat perkawinan. Hal-hal yang termasuk sebagai rukun perkawinan adalah sebagai berikut:

1. Pihak-pihak yang melaksanakan akad nikah yaitu mempelai pria dan wanita.

2. Adanya akad (sighat) yaitu perkataan dari pihak wali perempuan atau wakilnya $(i j a b)$ dan diterima oleh pihak laki-laki atau wakilnya (qabul). 
3. Adanya wali dari calon istri.

4. Adanya dua orang saksi.

Apabila terdapat salah satu syarat sebagaimana disebutkan diatas tidak terpenuhi, maka perkawinan yang dilangsungkan dianggap tidak sah dimata hukum, bahkan dapat dipastikan bahwa perkawinan itu dianggap tidak pernah terjadi. Untuk itu apabila rukun dan syarat perkawinan belum terpenuhi, maka pasangan pengantin yang melangsungkan perkawinan tersebut belum diperbolehkan bahkan diharamkan untuk melakukan hubungan seksual. Namu jika empat rukun tersebut sudah dapat dipenuhi maka perkawinan yang dilakukan oleh para pihak dimaksud telah dianggap sah.

Perkawinan tersebut sudah telah dianggap sah dalam pandangan islam, jika dikaitkan dengan ketentuan sebagimana termaktub dalam pasal 2 (ayat 2) UU Nomor 1 tahun 1974 tentang perkawinan yang menyatakan : "Tiap-tiap perkawinan dicatat menurut peraturan perundang-undangan yang berlaku." Sebagai penegas ketentuan tersebut bahwa UU No 16 Tahun 2019 Tentang Perubahan Atas Undang-Undang No 1 Tahun 1974 Tentang Perkawinan memberikan pembatasan terhadap usia minimal perkawinan terhadap seorang Laki-laki dan wanita disamakan yakni 19 tahun. Tetapi apabila usia calon pasangan pengantin belum mencukupi batas minimal tersebut, pasal 7 ayat 2 UU tersebut menjelaskan bahwa perkawinan tetap dapat dilaksanakan dan disahkan yaitu dengan cara minta dispensasi pada pengadilan atau pejabat lain yang berwenang dan permintaan dispensasi tersebut dilakukan oleh kedua orang tua mempelai pria maupun mempelai wanita.

Norma Hukum dan Norma Agama telah bersinergi dan telah memberikan pengaturan dengan jelas mengenai hal-hal yang seharusnya diperhatikan dalam pelaksanaan perkawinan. Mulai dari syarat sahnya dan rukun perkawinan, bahkan beberapa hal penting lain demi tercapainya tujuan terbaik dari sebuah perkawinan menuju bahtera kehidupan berumah tangga. Namun berkaitan dengan perkawinan kontrak tidak terdapat satu pasalpun dalam perundang-undangan yang berlaku di Indonesia yang memberikan pengaturan mengenai kawin kontrak. Justru berdasarkan hasil analisis penulis apabila dikaitkan dengan berbagai peraturan perundangundangan yang berlaku di Indonesia mengenai perkawinan yang dilakukan secara kontrak oleh para pihak, keberadaanya tidak dapat dianggap sah dan diakui menurut hukum, karena jelas berdasar pasa materi mutan perjanjian dianggap sebagai telah melanggar ketentuan yang berlaku menurut pandangan hukum positif yang berlaku di Indonesia. 


\section{A. Kesimpulan}

\section{IV.PENUTUP}

Perkawiwan kontrak banyak terjadi dilakukan di Indonesia yang pada umumnya pelakunya antara pihak berwarga Negara asing dengan pihak warga Negara Indonesia. Namun secara khusus pengaturan mengenai kawin kontrak sampai saat ini belum ada diatur dalam ketentuan peraturan perundang-undangan yang berlaku di Indonesia, oleh karena itu wajar jika praktik-praktik perkawinan tersebut banyak terjadi di Negara Indonesia ini.

\section{B. Saran}

Seyogianya pemerintah Indonesia harus mulai bersikap terhadap adanya praktik-praktik perkawinan kontrak tersebut, mengingat secara hukum, baik norma hukum maupun norma agama perkawinan yang demikian itu dianggap tidak patut untuk dilakukan, karena jelas-jelas bertentangan dengan kemurnian dan ksucian hakikat tujuan perkawinan, misalnya dengan membentuk peraturan untuk memberikan pengaturan terhadap kawin kontrak tersebut sehingga diharapkan akan ada akibat hukum bagi para pihak yang melakukan perkawinan kontrak tersebut.

\section{DAFTAR PUSTAKA}

Abdurrahman,1986,Himpunan Peraturan Perundang-undangan Tentang Perkawinan. Jakarta : Akademika Pressindo.

Ensiklopedi Indonesia,1982, Jilid 3, Jakarta: Ichtiar baru-Van Hoeve.

Hans Kelsen,2002,Pure Theory of Law, terjemahan Max Knight dari reine Rechtslehre. The Law book Exchange Ltd.

H.C. Black, Black's Law Dictionary, West publishing Co. St. Paul Minn.,

J.van Kan dan J.H. Beekhuis,Pengantar Ilmu Hukum,Pustaka Sarjana,tanpa tahun.

Muhammad Jawad Mughniyyah, 2001,Fiqh Lima Madzhab, Lentera, Jakarta.

Soemiyati, 1986,Hukum Perkawinan Islam dan Undang-undang Perkawinan,Liberty, Yogyakarta.

Salim HS,2011,Pengantar Hukum Perdata Tertulis (BW),Sinar Grafika, Jakarta.

Soebekti,2001,Hukum Perjanjian,Cet 18,PT.Intermasa,Jakarta. 
Wahjono Darmabrata dan Surini Ahlan, Hukum Perkawinan dan Hukum Keluarga Indonesia,2004 Fakultas Hukum Universitas Indonesia,Jakarta.

Kitab Undang-Undnag Hukum Perdata (KUH Per)

Undang-Undang Nomor 1 Tahun 1974 Tentang Perkawinan

Undang-Undanag Nomor 16 Tahun 2019 Tentang Perubahan atas Undang-Undang Nomor 1 Tahun 1974 Tentang Perkawinan

Kompilasi Hukum Isalam (KHI)

Kitab Undang-Undnag Hukum Perdata (KUH Per)

https://updatetalas.wordpress.com/2016/09/28/pengertian-nikah-kontrak/

https://id.wikipedia.org/wiki/Hukum_positif\#: :text=Hukum\%20Real\%20 (Bahasa\%20Latin\%3A\%20ius, mewajibkan\%20atau\%20menetapkan \%20suatu\%20tindakan.\&text=Hukum\%20positif\%20juga\%20dides kripsikan\%20sebagai,sekarang)\%20dan\%20di\%20tempat\%20tertent u. Diakses pada tanggal 30/6/2020 pada pukul 12.05 Wita.

https://muslim.okezone.com/read/2019/12/24/614/2145587/ini-penjelasanlengkap-tentang-hukum-kawin-kontrak-dalam-islam?page $=2$

https://www.hukumonline.com/berita/baca/hol15650/kawin-kontrakantara-agama-hukum-dan-realita/ 